\title{
Pendidikan Diniyah Formal : a Formal Curriculum for Pesantren in Indonesia
}

\author{
Ahmad Syukron $^{1 凶}$, Samsudi $^{2} \&$ Kustiono $^{2}$ \\ ${ }^{1}$ Vocational High School Syafi'i Akrom, Pekalongan, Jawa Tengah, Indonesia \\ ${ }^{2}$ Mechanical Engineering Education, Universitas Negeri Semarang, Indonesia \\ ${ }^{3}$ Education Technology, Universitas Negeri Semarang, Indonesia
}

\begin{abstract}
Article Info
History Articles

Received:

December 2019

Accepted:

January 2020

Published:

November 2020

Keywords:

formal curriculum,

$p d f$,

pesantren

DOI

https://doi.org/10.15294

/ijcet.v9i2.36645

Abstract

Starting from 2015, the ministry of religions and affairs of Indonesia has developed a type of formal education service, specially for pesantren by announcing Pendidikan Diniyah Formal (PDF). Some pesantren in Indonesia have implemented this kind of curriculum, so that it is necessary to conduct a study related to its implementation in order to acquire the whole description of its actualization in pesantren. This study aims to describe the implementation of PDF at APIK (Asrama Pendidikan Islam Kaliwungu), one of pesantren in Kaliwungu. This study belongs to case study and uses qualitative approach. The data were collected through interview, observation, and documentation in order to know the planning, implementation, and evaluation process of PDF. This study uses the model of Miles and Huberman which includes data reduction, data display, and conclusion drawing in analyzing the data. The research result shows the implementation of PDF at APIK including its learning objectives, materials, sources, time allotment, as well as the evaluation system has been appropriate with the basic rule of PDF established by the government. However, it still remains the specific characteristics of pesantren, including its local content, classroom management, as well as the learning strategy used such as bandongan and sorogan. The result of this study can be used as reference for other pesantren applying PDF and to facilitate some pesantren which have applied PDF in spreading its existence among Indonesian people, so that their graduates can be accepted in higher education institution as well as other formal institutions.
\end{abstract}




\section{INTRODUCTION}

Pesantren is the oldest Islamic Educational institutions in Indonesia which keeps giving important contributions in the social and religious affairs (Zulfiqar, 2017). The existence of pesantren has been avowed, especially in Java since the $17^{\text {th }}$ century (Halil, 2015). Its admission, then, expanded by the emergence of some kiai (experts in Islam) graduated from pesantren and have considerable influence in the social order in Indonesia (Muhakamurrohman, 2014). Moreover, the existence of pesantren which has existed before formal education makes it considered as educational institution that has strong roots in the Indonesian Muslim society.

According to Haedari (2004), pesantren has participated in succeeding the national development goals, and at the same time it has also played an active role in educating the nation in accordance with the 1945 constitution. Nasir (2005) opines that pesantren used to be a religious learning activity reciting kitab kuning (classic books) held in a mosque or majelis taklim (learning meeting) using traditional and simple system without any grade level. Then, from this condition, pesantren is getting off the ground, and its existence is recognized under the supervision of the ministry of religions and affairs of Indonesia (Zuhdi, 2006). This development process makes pesantren able to survive in responding changes even to occupy a central position in the scientific world.

Ahmad Zayadi, the director of religious education and Islamic boarding school of the ministry of religions and affairs states that the number of pesantren in 2016 according to the data from the ministry of religions and affairs coming at 28,194 (republika.co.id., 2017). It shows that in recent decades, pesantren has developed greatly, both in rural, suburban and urban areas. This great development of pesantren caught the attention of the Indonesian government. That is why, the government, then, made a regulation number 55 in 2007 containing religious education including Pendidikan Diniyah Formal.

The existence of PDF shows regeneration in the education system of pesantren, which changes from nonformal into formal education system. This condition encourages some host pesantren of PDF to consider the curriculum as a reference in running a formal education activity. Its curriculum development is nationally standardized in the basic framework containing the integration of Islamic and general knowledge.

There are some previous studies related to PDF which have been conducted before. One of them is a study conducted by Suroso (2017). Its result shows that the management and learning process of PDF applied in the Islamic boarding school of Assalafi Al Fithrah have worked well. It can be seen from the planning of learning objectives and material, its realization, time allotment, as well as evaluation type used are appropriate for the level of wustho (intermediate level). In addition, Wahid (2016) has conducted a research related to Pendidikan Diniyah Formal as well. His research, which is a library research, discussed about PDF used as new educational model for forming the cadres of ulama'. The result shows that PDF curriculum is a curriculum which provides greater Islamic knowledge portion than general knowledge, so that it is supposed to be able to create muttafaqih fiddin graduates (expert in Islamic knowledge).

From the explanation of the previous paragraph, it can be concluded that both of the previous studies are different with this study. It is because this study focuses on the implementation of PDF curriculum in the level of ulya (advanced level) by using case study. Because it belongs to new curriculum, this study aims to investigate the implementation of its curriculum in detail in order to know the whole description of its implementation. The result of this study is supposed to be able to be used as reference for other pesantren applying PDF and to facilitate some pesantren which have applied PDF in spreading its existence among Indonesian people, so that their graduates can be accepted in higher education institution as well as other formal institutions. 


\section{METHODS}

This study belongs to qualitative research by using case study. According to Creswell (2013), case study explores a real-life, contemporary or multiple bounded system over time, through indepth data collection involving multiple sources of information and reports a case description as well as case themes.

The study was conducted in APIK, one of Islamic boarding school in Kaliwungu, Kendal regency. Research data were collected through interview, observation, and documentattion. The technique of interview was used to explore some information related to the implementation of PDF from the headmaster, vice principal, as well as the teachers. In the case of observation, it was used to directly observe the implementation of $\mathrm{PDF}$, especially its learning process in the classroom, and the documentation was used to collect the relevant documents used in PDF curriculum, such as PDF rules, the learning material, report card, relevant articles and books, etc.

The data analysis of this study was carried out before and after coming to the research location. This study uses the model of Miles and Huberman through understanding the meaning of data presented in the location and after leaving the location (Sugiyono, 2013). This activity was carried out through some steps, including data reduction or simplification, data display, and data verification or concluusion drawing (Ali, 1992).

\section{RESULTS AND DISCUSSION}

\section{Planning of PDF Curriculum}

The Islamic boarding school of APIK begins its PDF implementation by making a curriculum planning. Based on the interview result, it was found that curriculum planning at APIK boarding school is carried out since Sya'ban Month or two months before the school year begun. It is started with the appointment of teachers by the boards of foundation, then, the committee divides the subjects for each teacher, and the result is given to the board of foundation to be validated. When the learning process has been carried out for a month, there will be a meeting discussed about some efforts that will be done to strengthen what has been planned before, such as the learning material, or teaching strategies used. This condition shows that the curriculum planning has involved several parties, starting from the board of the foundation, administrators, to all teachers.

Obanya and Sarason cited in Maphosa and Mutopa (2012) stated that it is necessary to involve some parties, especially teachers in planning a curriculum. It is because teachers are the main actors that can identify the curriculum weaknesses and adjust it with any improvement needed. In other word, what APIK has been done in planning the curriculum is in accordance with the previous statement.

However, practically, although it is under the formal education system, its curriculum planning has not been organized and documented well. Based on the result of interview and documentation, it was found that there is no planning documents including syllabus and lesson plan. The planning is only done by following the material written in the book.

Rino (2017) stated that ideally the curriculum planning is documented in the documentation of KTSP consistingof three main books, namely general user guide, syllabus, and lesson plan. It means that what happened in the curriculum planning of APIK has not been in accordance with the ideal conditionof formal education. However, Nurcholis Madjid cited in Junaidi (2016) opined that most of pesantren do not make its learning basis and objectives in a curriculum documentation. Fathurrochman (20179) and Takdir (2018) also stated that generally, pesantren's curriculum is in the form of manhaj in which the learning material plot is appropriate with the plot of the book, and it is usually not arranged in detail and without any formal rule. This opinion is in accordance with the conditions of APIK in planning its curriculum.

Based on the result of interview and documentation study, it was found that the stages which have been carried out by Islamic boarding school of APIK in curriculum planning are as 
follows: The first is determining the goal. There are some goals in implementing PDF including national, institutional, curricular, as well as instructional goal. These kind of goals are in line with the statement of Abdullah Idi (2016) as cited in Ma'arif dan Rofiq (2018) who stated that educational goals consist of national, institusional, curriculum, and instructional goals. The national education goal is implicit in the general goal of PDF, while the institutional goals are implicit in the vision, mission and objectives of each pesantren.

The result of interview and documentation show that the main goal of PDF curriculum is to create muttafaqih fiddin (expert in Islamic knowledge). According to M. Dian Nafi' (2007) and Wahid dalam Nurhayati (2010), that goal has been appropriate with the developing curriculum pattern which aims to create ulama'. Beside that, it is also related to the national educational goal that aims to create good civilization.

In addition, APIK also has institusional goal arranged by the founder of pesantren, curricular goals adjusted to the curriculum structure, as well as instructional goals arranged by the teachers of each subject. In this case, those objectives are not arranged in detail because the main focus of APIK is on how the learning material is delivered. This condition is in accordance with the statement of Qamar (2005) cited in Saekhotin and Anam (2017) who stated that as an educational institusional, pesantren has some goals including institusional, curricular, and instructional goals, but they are not clearly formulate. Those goals are commonly not stated in written form. Therefore, many pesantren researchers formulate their goals based on estimation only.

The second curriculum planning is the arrangement of curriculum content. Based on the result of documentation and interview, it was found that the subjects determined in the stage of planning include Islamic and general knowledge referred to the curriculum structure, and local content developer by the teachers of each subject.

This condition shows that the curriculum content of APIK has been appropriate with the curriculum structure of Ulya stated on the decree of the Director General of Islamic Education. It includes Al-Qur'an, Tafsir-Ilmu Tafsir, Hadits, Tauhid, Fiqh-Ushul Figh, Akhlaq-Tasawuf, Tarikh, Arabic language, Nahwu-Sharf, Balaghah, Ilmu Kalam, Ilmu Arudh, Ilmu Mantiq, Ilmu Falak. In the case of general knowledge, it includes Pendidikan kewarganegaraan, Bahasa Indonesia, Mathematics, Science, as well as Arts and Culture. Moreover, there are also some local contents which include Ilmu Mawaris, Qowaidul Fiqh, Musyawarah, Bahsul Masail, and Khitobah.

In arranging the curriculum content, APIK also determines the learning sources used as refernce. Based on the documentation study, it was found that the learning sources of the Islamic knowledge are based on kitab kuning (classic books) determined by the government. However, the sources of general subject and local content are developed by the teachers of each subject. It is because there is no certain standard given by the government. In this case, then, the teachers of APIK use textbooks for teaching the general subjects, and some claassic books for teaching the local content.

Moreover, in determining the content of curriculum, APIK also considers the learning time management. It is, of course, based on the curriculum structure. It includes the arrangement of academic calendar, determination of effective days, holidays, examination period, etc. In the case of academic calendar arrangement, APIK usually uses Hijri calendar (Islamic calendar). That is why the shool year is always started in Shawwal and ended in Syaban.

The third stage in curriculum planning is the determination of learning methods. In this case, APIK usually plans to use the common methods used in pesantren, namely bandongan, sorogan, musyawarah (discussion), and muhafadzah (memorization). The teachers believe that eventhough those methods belong to tradisional ones, the use of those methods will bring positive effects. It is in accordance with Dhafier's statement (1982) as cited in Syafe'i (2017) who stated that learning methods used in traditional pesantren such as musyawarah (discussion) can train and test the mental maturity of the students, so that they will be strong religious people. 
The forth stage in curriculum planning is the determination of evaluation program. It is used to monitor students' achievement. There are some elements that should be considered in planning evaluation program. It includes the domain of its competence, its evaluation type, as well as its timing. In this case, the evaluation planning arranged by APIK includes the aspect of attitude, knowledge, as well as skills. The evaluation types include written and oral test, practical activity, and muhafadzah. Those evaluation program are usually planned to be carried out daily, monthly, in the mid of the semester, at the end of the semester, at the end of the school year, and at the end of the program. This condition shows that APIK, as one of pesantren applying PDF, is different with other traditional pesantrens that have no such formal evaluation program.

The last stage in curriculum planning is the determination of students' self-development. The students' self-development carried out by APIK is in the form of some extracurricular activities. They are sports which include futsal, volleyball, pencak silat (traditional self-defence arts), and tambourine. Beside that, there is also extracurricular related to falaqiyyah, Arabic language, journalism, multimedia, etc.

\section{Implementation of PDF Curriculum}

In this step, APIK tries to implement the designed curriculum program before. In realizing it, APIK always considers to several elements that can support the curriculum implementation, such as teachers' planning, classroom management, learning methods, learning media, as well as students' assessment. This condition is in accordance with the statement of Hamalik (2010) and Fullan (2002) who stated that curriculum implementation needs the support of three main factors. The first factor is human factor including teachers, students, school principal, supervisor, and parents. The second factor is material factor including learning sources and infrastructure. The last one is procedural factor which includes learning strategies, classroom management, and students' assessment as well.
The explanation of those elements will be explained as follows: The first is teachers' planning. The learning planning done by the teachers of APIK is still in a simple form. It is only in the form of planning related to the learning material scope that will be taught. In this case, the scope is usually adjusted to the plot line of the book used in the learning process. This condition is in line with the opinion of Karcher as cited in Saifuddin (2015), Fathurrochman (2017), and Takdir (2018) who opined that in general, the learning plan made by the teachers in pesantren is in the form of manhaj (learning which is based on the plot line of the book). In addition, it is also usually not arranged in detail and without any formal provision.

The second one is classroom management. In this case, the classroom Management carried out by APIK is like other tradisional pesantren, in which both the teacher and the students sit on the floor by using small tables. It means that APIK has arranged the classroom management in such way. This condition is in line with the statement of Marasabessy (2012) who stated that classroom management needs to be considered in the learning implementation.

The third element is learning method. In the learning process, the use of appropriate methods can help the achievement of learning objectives (Pupuh and Sobry S, 2010) and Nasution (2017). In this case, APIK uses common method used in traditional pesantren, such as bandongan, sorogan, discussion, as well as muhafadzah (memorization). The teachers believe that eventhough those methods belong to tradisional ones; the use of those methods will bring positive effects. It is in accordance with Dhafier's statement (1982) as cited in Syafe'i (2017) who stated that learning methods used in traditional pesantren such as musyawarah (discussion) can train and test the mental maturity of the students, so that they will be strong religious people.

The forth element is learning media. Practically, Most of APIK teachers use less of learning media. This condition is influenced by the habbits occured in traditional pesantren in which its learning process is carried out simply 
without using various media. However, there are some teachers that have used some media such as projectors. It is usually used for practical learning that requires video shows.

The fifth element is the assessment of learning outcome. After carrying out the learning activities, the teachers of APIK carry out the learning assessment. It includes assessment of attitude, knowledge, and skills. The type of its assessment can be in the form of written tests, oral tests, practice, and muhafadzah (memorization). Its realization can be carried out daily, weekly, monthly, in the mid of the semester, the end of the semester, end of the school year, and end of the program as well.

The assessment of students' attitude is applied to all subjects. It can be carried out through direct observation during the learning process. It becomes the strongest consideration in the grade promotion criteria.

In the case of assessing students' knowledge, the teachers usually establish it on muhafadzah (memorization). There are some muhafazah assessments carried out by the teachers daily, monthly, in the end of the semester, and at the end of the school year through mukhafadzah sema'an. In this case, the students should minimally deliver the recitation up to 60 nadhom (rhymes) in a month. This condition is in line with Ma'arif and Rochmah (2018) who stated that the target of mukhafadzah becomes a tradition for traditional pesantren in Indonesia. It is because it can be used to controll the students' learning outcome as well as to increase students' learning motivation.

On the other hand, the assessment of students' skill is not always been carried out like the attitude and knowledge skills. It is only carried out in some subjects with practice activity in it. The subjects include Figh, Arts and Culture, and Arabic language.

Beside that, APIK also carries out other assessment program, such as midterm and final exams, as well as Imtihan Wathani (national examination for PDF). This kind of assessment is usually called as summative assessment. Its implementation is coordinated by committees that have to be responsible for managing everything starting from drafting to reporting students' achievement. This process is, then, followed up by reporting the students' score documented in the report card.

In the PDF curriculum system, there is a kind of national examination. It is called as Imtihan Wathani. It emphasizes that the implementation of PDF curriculum is really nationally standardized. The standardization is not only on its curriculum content, but also its learning outcome. In this case, APIK has implemented this kind of evaluation system for the students in the highest level.

In addition, the learning assessment of $\mathrm{PDF}$ is also completed with minimal achievement standard for each subject, report card, formal certificate, grade promotion criteria, and graduation criteria as well. However, the grade promotion and graduation requirement applied by APIK is more emphasized on students' behavior and attitude than their knowledge.

\section{Evaluation of PDF Curriculum}

The implementation of PDF curriculum in APIK is also completed by having evaluation process. It is done in order to know the achievement of the expected goals. This condition is in accordance with Tyler's statement as cited in Djemari Marpadi (2012) and Andrian (2018), who opined that curriculum evaluation is the stage of finding information related to the achievement of curriculum implementation. Hamalik (2012), and Nasution as cited in Rino (2017) also added that curriculum evaluation aims to find out the achievement of educational goals including student progress, curriculum effectiveness and its factors.

Beside that, APIK also uses the evaluation result to update and redesign a better curriculum to be applied in the next school year. It is in line with the statement of Sukmadinata (2011) and Eisner as cited in Rino (2017) who opined that the results of the curriculum evaluation can be used to develop or revise curriculum, predict learning needs, set achievement goals, and choose appropriate learning materials and learning strategies. 
In its realization, the curriculum evaluation in APIK is focused on two components including the learning process and learning outcomes. This condition shows that what has been done by APIK is in line with the statement of Print as cited in Rino (2017) who explained that curriculum evaluation can be carried out on two components namely learning process and learning outcomes. Moreover, it also evaluates the effectiveness of curriculum implementation as stated by Hamalik (2013) that the effectiveness of curriculum implementation is one of the curriculum elements that should be evaluated.

The evaluation process carried out by APIK includes the evaluation of its learning process, the learning strategies used, as well as students' learning development. It is in accordance with the statement of Zedda, Bernardelli, \& Maran (2017) who opined that there are some elements to be evaluated in the curriculum implementation. It includes learning method, students' satisfaction in the learning process, as well as their learning achievement

Generally, the evaluation process in PDF is done through formative assessment or direct observation. Formative assessment is usually done to monitor students' learning progress. In the learning scope of pesantren, this kind of evaluation has been carried out intensively on each student. It can be seen from the use of sorogan as one of learning methods. Sorogan carried out by having face to face between students and teachers, can be used to detect students' learning achievement, even describe their characteristics. Moreover, APIK also has evaluated the students' learning achievement through summative assessment such as midterm and final exams, as well as Imtihan Wathani (national examination for PDF).

Usually, the curriculum evaluation is conducted by APIK after a month of learning process. It is done by having a deliberation involving all teachers to find out the effectiveness of curriculum implementation. The next evaluation is usually carried out at the end of the semester and the end of the school year. Moreover, there is also conditional evaluation carried out sometime. The conducted evaluation in APIK is still in the form of internal evaluation. There is no external evaluator such as supervisor or assessor. Based on the study documentation on the rules made by the ministry of religious and affairs number 13 in 2014, it is found that there should be educational supervisor and accreditation activity in the implementation of PDF curriculum.

Based on the explanation above, it can be concluded that the model of curriculum evaluation carried out by APIK is in the form of Formative vs Sumative Evaluation. As cited by Darojat (2015), Brinkerhoff, et.al. (1983) classified the curriculum evaluation model into three types, namely Fixed vs Emergent Evaluation Design, Formative vs Sumative Evaluation, and Experimental and Quasi Experimental Designs vs Unobtrusive Inquiry.

\section{CONCLUSION}

The existence of PDF gives a new nuance to traditional pesantren. It shows an effort to formalize the educational system from nonformal to the formal one. It is done by adjusting its implementation with the standardized rules from the government nationally. By using PDF, the educational system of pesantren which basically uses traditional system without any formal rules, should follow an aranged system from the government. The emergence of PDF has contributed to formal education in Indonesia. It is because the type of formal education only provides formal schools at the beginning, but now, it can be a new alternative for Indonesian people who want to focus on studying Islamic knowledge through formal education system of pesantren.

\section{REFERENCES}

Abdullah. (2016). Kurikulum Pesantren dalam
Perspektif Gus Dur; Suatu Kajian
Epistemologis. Jurnal Pendidikan Agam Islam. 4
(2): $228-248$. Retrieved from
$\underline{\text { http://dx.doi.org/10.15642/jpai.2016.4.2.227 }}$
$\underline{-248}$ 
Ali, Muhammad. (1992). Penelitian Kependidikan Prosedur dan Strategi, Bandung: Angkasa.

Andrian, D., Kartowagiran, B., \& Hadi, S. (2018). The Instrument Development to Evaluate Local Curriculum in Indonesia. International Journal of Instruction, 11(4), 921-934. Retrieved from https://doi.org/10.12973/iji.2018.11458a

Arends, Richard. (2008). Learning to Teach. Avenue of the Americas New York: McGraw-Hill Companies.

Arikunto, Suharsimi, Abdul Jabar \& Cepi Safruddin. (2009). Evaluasi Program Pendidikan. (Edisi 2, Cetakan 1). Jakarta: PT. Bumi Aksara.

Bashori. (2017). "Modernisasi Lembaga Pendidikan Pesantren Perspektif Azyumardi Azra". Jurnal Pendidikan Islam- Nadwa. 11 (2): 296-296.

Creswell, J. W. (2013). Qualitative Inquiry \& Research Design: Choosing among Five Approaches (3rd ed.). Thousand Oaks, CA: SAGE.

Fathurrochman, Irwan. (2017). "Implementasi Manajemen Kurikulum Dalam Upaya Meningkatkan Mutu Santri Pondok Pesantren Hidayatullah/Panti Asuhan Anak Soleh Curup". TADBIR: Jurnal Studi Manajemen Pendidikan. vol. 1, no 01. STAIN Curup Bengkulu | p-ISSN 2580-3581; e-ISSN 25805037

Fullan M. (2002). The change leader. Educational Leadership, 59(8): 16 -21.

Haedari, Amin, et al. (2004). Masa Depan Pesantren dalam Tantangan Modernitas dan Tantangan Komplesitas Global. Jakarta: IRD Press.

Halil, Hermanto. (2015). "Inovasi Kurikulum Pesantren Dalam Memproyeksikan Model Pendidikan Alternatif Masa Depan". Ulûmunâ: Jurnal Studi Keislaman. Vol.1 No.2 Desember 2015 : ISSN 2442-8566

Hamalik, Oemar. (2012). Manajemen Pengembangan Kurikulum. Bandung: PT. Remaja Rosda Karya.

Hamalik, Oemar. (2013). Kurikulum dan Pembelajaran. Jakarta: Bumi Aksara.

Junaidi, Kholid. (2016). Sistem Pendidikan Pondok Pesantren Di Indonesia (Suatu Kajian Sistem Kurikulum di Pondok Pesantren Lirboyo). Istawa: Jurnal Pendidikan Islam. 2 (1) : 95 - 110. Retrieved from

http://journal.umpo.ac.id/index.php/istawa/ article/view/364

Lamm, Z. (1969) Teaching and Curriculum Planning, Journal of Curriculum Studies, 1:2, 159-171, DOI: 10.1080/0022027690010206. Published online: 29 Sep 2006
Ma'arif, MA., Rofiq, MH. (2018). Pola Pengembangan Kurikulum Pendidikan Pesantren Berkarakter. Tadris. 13 (1): 1 - 16

Ma'arif, MA., Rochmah, S. (2018). Target Hafalan sebagai Motivasi Belajar dalam Membentuk Karakter di Lingkungan Pesantren. Muróbbî: Jurnl Ilmu Pendidikan. 2 (1): 105 - 127

Maphosa, C. \& Mutopa, S. (2012) Teachers'Awareness of Their Role in Planning and Implementing School-based Curriculum Innovation, The Anthropologist, 14:2, 99-106, DOI: 10.1080/09720073.2012.1189122

Mardapi, Djemari. (2012). Pengukuran Penilaian dan Evaluasi Pendidikan. Yogyakarta: Nuha Litera

Muhakamurrohman, Ahmad. (2014). Pesantren: Santri, Kiai, dan Tradisi. Jurnal Kebudayaan Islam - Ibda'. 12 (2) : 109-118.

Nafi', M. Dian. (2007). Praksis Pembelajaran Pesantren. LkiS: Yogyakarta.

Nasir, Ridlwan. (2005). Mencari Tipologi Format Pendidikan Ideal: Pesantren Di Tengah Arus Perubahan.Jogjakarta: Pustaka Pelajar.

Nasution, MK. (2017). Penggunaan Metode Pembelajaran Dalam Peningkatan Hasil Belajar Siswa. Studia Didaktika: Jurnal Ilmiah Bidang Pendidikan. (11) 1: 9-17

Nilan, P. (2009). "The 'spirit of education' in Indonesian Pesantren". British Journal of Sociology of Education, 30:2, 219-232. Vol. 30, No. 2, March 2009.

Nurdin, Syafruddin. dan Adriantoni. (2016). Kurikulum dan Pembelajaran. Jakarta: Rajawali Pers.

Nurfaradila, Madhakomala, dan Amril (2014). Pengelolaan Kurikulum Untuk Peningkatan Kualitas Lulusan. Jurnal Improvement. 1 (1). Retrieved from https://jurnalimprovement.wordpress.com

Pupuh Faturrohman \& Sobry M. S. (2010). Strategi Belajar Mengajar melalui Penanaman Konsep Umum \& Konsep Islami. Bandung: Refika Aditama

Rizal, Ahmad. (2011). "Transformasi Corak Edukasi dalam Sistem Pendidikan Pesantren, dari Pola Tradisi ke Pola Modern". Jurnal Pendidikan Agama Islam - Ta'lim. 9 (2): 95 - 112.

Rusdi, Rino. (2017). Kurikulum, Perencanaan, Implementasi, Evaluasi, Inovasi, dan Riset. Bandung: Alfabet.

Saekhotin, Sayyidah., Anam, Nurul. (2017). Improvisasi Pesantren Sebagai Subkultur di Indonesia. Al Qodiri: Jurnal Pendidikan, Sosial, dan Keagamaan. 12 (1): $34-60$ 
Shofiyyah, NA., Ali, H., Sastraatmadja, N., Model Pondok Pesantren di Era Milineal. Belajea: Jurnal Pendidikan Islam. 4 (1): 1-18. DOI: 10.29240/belajea.v4i1.585

Sugiyono. (2013). Metode Penelitian Pendidikan Kuantitatif, Kualitatif dan $R$ dan D. Bandung: Alfabet.

Sukmadinata, Nana Syaodih. (2011). Pengembangan Kurikulum: Teori dan Praktek. Bandung: PT Remaja Rosdakarya Offset

Suroso. (2017). "Manajemen Pembelajaran Pendidikan Diniyah Formal (PDF) Tingkat Wustho Pondok Pesantren Assalafi Al Fitrah Surabaya". Adabiyah Jurnal Pendidikan Islam. 2(1). $73-106$

Syafe'i, Imam (2017). Pondok Pesantren: Lembaga Pendidikan Pembentuk Karakter. AlTadzkiyyah: Jurnal Pendidikan Islam. 8 (1): 85 103
Takdir, Mohammad. (2018). Modernisasi Kurikulum Pesantren. IRCiSoD: Yogyakarta.

Zedda, M., Bernardelli, S., \& Maran, D. A. (2017). Students' Satisfaction with the Group Work Method and its Performance Evaluation: A survey in an Italian University. International Journal of Instruction, 10(3), 1-14. Retrieved from https://doi.org/10.12973/iji.2017.1031a

Zuhdi, Muhammad. (2006). "Modernization of Indonesian Islamic schools' curricula, 19452003". International Journal of Inclusive Education, Vol. 10, No. 4-5, July-September 2006: $415-427$

Zulfiqar, S. (2017). Multilingual Teaching and Learning at Pesantren Schools in Indonesia. Asian EFL Journal, Professional Teaching Article, Vol. 98, Feb 2017: 74-94. Retrieved from http://www.asian-efl-journal.com 